\title{
Using "Deep Learning School” with Digital Technologies in Science and Technology
}

\author{
Aislu T. Kurbanova ${ }^{1 *}$, Yuri N. Yarovikov ${ }^{2}$ \\ ${ }^{1}$ Institute of Psychology and Education, Kazan Federal University, 420008, Kremlevskaya 18, Kazan, RUSSIA \\ 2 Phystech School of Applied Mathematics and Informatics, Moscow Institute of Physics and Technology, 141701, Dolgoprudny \\ (Moscow region, Russia), RUSSIA
}

Received 14 March 2021 • Accepted 7 June 2021

\begin{abstract}
A digital technology of education and career guidance was created within the open free resource "Deep Learning School" (DLS). The mission of DLS is recruiting and education of talented youth in the field of IT research and development. DLS technology assumes the possibility of online training; in the absence of pandemic-related restrictions, a mixed format is available. The principles of DLS as an educational technology and a technology for professional selfdetermination of various contingents of young people are described. Empirical material - the results of an anonymous online survey of 145 DLS listeners - specialists, undergraduate and graduate students, applicants. A qualitative analysis of open-ended questions revealed the functions of DLS, which concretize its mission as an educational technology and a technology of professional self-determination. The possibilities of online and offline components of the technology are concretized to achieve actually didactic, educational goals, goals of socialization and facilitation of professional self-determination; revealed the specificity of their use by various contingents of students. The high efficiency of the technology for recruiting talented young people with high motivation to get education and work in the field of machine intelligence is shown. The research results can be used by specialists to improve the efficiency of digital educational resources and improve the practice of career management.
\end{abstract}

Keywords: digital educational technologies, science, technology, career guidance work, professional self-determination, machine learning

\section{INTRODUCTION}

The COVID-19 pandemic-related restrictions forced to translate pedagogical practices, which were previously carried out in mixed or offline formats into the remote format. The achievement of basic purposes in the changed conditions demanded additional understanding of the functionality of educational programs and technologies. Universities modify the tools for forming the contingent of students and professional career management. Moscow Institute of Physics and Technology (MIPT) is a leading university of the country in the promising area of Deep Learning a digital technology associated with Data Science. Deep Learning is one of the most dynamically developing areas of artificial intelligence associated with teaching neural networks, computer vision and natural language processing (Goodfellow et al., 2016; LeCun et al., 2015). Deep Learning School (DLS) was created at MIPT as a youth career management tool (university graduates, students and schoolchildren), its mission is recruiting talented youth and distributing competencies to work in the Data Science.

DLS is a free course that does not pursue commercial purposes. Its specificity is a high degree of innovation and complexity; only a small part of listeners enrolled for a course completely mastered it. DLS is a dynamic and flexible technology; developers strive to optimize it and make it more accessible to various groups of the target audience, but consider it unacceptable to simplify the content of the course. 


\section{Contribution to the literature}

- It is shown that in order to recruit young people into the field of Data Science, educational technology should perform the following functions: education, learning, socialization and facilitation of professional self-determination.

- It was revealed that, according to the listeners, distance and live classes differ from each other in the ability to perform certain functions such as education, learning, socialization and facilitation of professional selfdetermination.

- It was found that most students would prefer to study DL in "face-to-face" classes or in combination with a video course.

- When recruiting for the Data Scientist profession, it is necessary to take into account that the distance learning format is most acceptable for undergraduate and graduate students, less so for university graduates, and is ineffective for schoolchildren.

\section{Purpose and Objectives of the Study}

The purpose of research is to determine the directions of optimization of DLS technology as a career management tool (professional orientation and professional self-determination) of various categories of listeners

\section{Objectives}

- clarification of the DLS functionality as a career management tool in the Data Science field;

- comparison of efficiency of online and offline forms of training for professional selfdetermination of young people;

- valuation of efficiency in various contingents of listeners - schoolchildren, students and graduates of universities.

\section{Literature Review}

Attraction and selection of talented youth is an important task of higher education (Radchenko, 2011; Tugun et al., 2020; Wiese et al., 2010; Yermilova et al., 2019). Modern universities integrate the functions of education with research and development and thus act as the development "locomotives" of various areas of science and practice. Providing human resources for the most dynamically changing areas requires learning throughout life (Gimaliev et al., 2020; Gorshkov \& Klyucharev, 2011; Razumovskaya et al., 2018, 2019). The higher school needs new career management tools addressed to various age and professional groups (Professionalising career guidance, 2009). Universities are leaders in Computer Science and IT-industry that carry out recruiting talented young people in this promising sphere due to various educational projects for students and specialists. The profession of Data Scientist is one of the most demanded and promising in IT. Its mastering is impossible without a high "entrance level" of competencies and increased motivation for the development of the profession (Broadbent \& Poon, 2015; Chen \& Jang, 2010).
Admission to Russian universities is mainly based on the results of tests at the end of secondary school, which limits the possibilities of the university to form a student corps (Tolstoguzov, 2015). There is an acute problem of alternative tools for professional orientation and professional self-determination of applicants and students (Shafranov-Kutsev \& Tolstoguzov, 2014), including using digital technologies (Shinkevich et al., 2020; Tsarapkina, 2017). In the field of Computer Science and IT-Industry Postgraduate education and retraining is a fundamental condition for successful work in the profession. Top Universities are developing innovative career management tools for those involved in this area at all stages of professional socialization. In a pandemic situation, distance career management tools and professional orientation practically ousted traditional forms (Sukhareva, 2019). It demanded an additional study of factors to form the motivation and interest of consumers of digital educational technologies (Buhr et al., 2019; Hsu et al., 2019; Kalugina et al., 2018; Kvon et al., 2019; Salikhova et al., 2020; Sun et al., 2019; Wang et al., 2019).

\section{METHODOLOGY}

The DLS technology study involved theoretical and observational methods, interviews with project developers and managers, as well as with lecturers and tutors.

Empiric material was obtained as a result of an anonymous voluntary online survey using the "Googleforms" resource. The "Deep Learning School Survey" questionnaire was developed as part of this research jointly with the school leadership and contained open and closed questions. The listeners were asked to assess the results of the DLS course, the content and organization of the educational process. The respondents assessed the effectiveness of offline and online education as a career management tool vocational guidance and professional selfdetermination. Some of the questions were addressed to all groups of DLS listeners, some - to schoolchildren and potential applicants. A qualitative analysis of answers to 
open-ended questions and a quantitative analysis of answers to closed-ended questions were carried out.

The sampling group consisted of DLS listeners ( $\mathrm{N}=145)$ : schoolchildren (10-11grade students) - 4.9\%; bachelors and specialty students - 29.7\%; master students $-8.4 \%$; specialists - university graduates $-57 \%$. Geography of the respondents' residence: Moscow $43 \%$; Moscow region - $13.3 \%$; residents of remote regions of Russia and other countries $-53.7 \%$.

The survey showed that the majority of respondents had a sufficient understanding of the content of the course and its organization: $75.9 \%$ received certificates of completion of the course; $13.8 \%$ completed the course, but did not score the necessary points to obtain a certificate; $4.1 \%$ mastered more than half of the course; $2.8 \%$ - mastered half of the course; $3.4 \%$ of respondents mastered less than a third of the program.

\section{RESULTS}

General characteristics of the DLS course. This is an open course implemented in Russian on the Stepik platform. Its target audience is comprehensive high school students, university students and graduates. DLS is a free, non-commercial course.

Forms of interaction with listeners. DLS technology includes face-to-face lessons (lectures by leading specialists in the Computer Science sphere and representatives of the IT-industry, as well as seminars with young teachers, graduates, successful students of senior courses of MIPT). Distant forms of worksystematic homework; various forms of current control (online testing with automated processing of results, peer-review, tutors and mentors control); regular webinars and consultations for course developers, teachers and assistants; students' independent projects; discussions in the training chat. All the offline forms of lessons are available in digital form (video lectures, video seminars), which is expanding the geography of the DLS use. In the absence of restrictions associated with a pandemic, the listeners independently select an acceptable combination of work forms offline and in a digital format.

\section{DLS Principles as a Technology of Vocational Guidance and Professional Self-Determination}

Focus on the implementation of the mission. Recruiting talented young people and distributing the Data Science competencies is the leading imperative defining targets, learning content, target audience, technology and DLS direction transformation.

Innovativeness. The translated content - DL competencies - reflects the "cutting edge" of Computer Science and IT technologies development.

High level of difficulty. DLS targets some of the more competent and motivated youth. The Data Scientist profession is one of the most promising, demanded and highly paid in the IT industry. Despite the high left out of listeners, developers avoid simplifying the content and reducing the level of requirements to educational results.

Non-commercial in nature. DLS is one of the forms of investment by MIPT in the development of human resources in the IT industry. Support of IT-corporations interested in DLS also contributes to the freedom from commercial use and makes it possible to maintain high requirements for students.

Heterogeneity of the audience. DLS technology is attractive, accessible for students of physical and mathematical classes as well as those of IT classes, who plan to enrol in specialized high schools. It is also attractive for undergraduate and graduate students; university graduates seeking to improve their qualifications or master a new field of work.

Variability. In the absence of restrictions related to the pandemic, listeners have an opportunity to select online or mixed learning format, independently vary the ratio of online and offline activities, the use of video content.

Intensive tutoring and mentoring. During the course, automated forms of control are replaced by nonautomated ones and are carried out "in manual mode". Assistance by a team of tutors and mentors consultations in the educational chat, webinars, offline and online consultations is becoming more and more personalized.

Adaptability. Regular feedback from listeners, analysis of the success of the course completion is the basis for improving DLS. The large left out rate of schoolchildren prompted a restructuring of the content and organization of the course. A propaedeutic module was developed, the purpose of which is to give a general idea about the Data Scientist profession, about specialized universities, higher schools, to acquaint with representatives of the industry. Modification direction of the DLS - the creation of regional offices, allowing enhancing offline forms of tutoring and mentoring, popular among students, has been defined.

Multifunctionality. Career management cannot be limited to teaching Data Scientist competencies. Attracting promising human resources requires taking into account other factors that contribute to the successful completion of the course and consolidation in the profession. Questionnaire "Deep Learning School Survey" is aimed at clarifying the structure of the functions that implement the DLS mission for adjusting the learning content and technology.

Creating and support of the school community. The DLS developers consider the possibility of personal contacts with teachers, including leading academics and DL and DS industry representatives, as well as "horizontal" contacts between listeners as the most important condition for the success of the course. In the pandemic, 
the community of DLS teachers, students and alumni confided itself to a digital format, which places increased demands on community management.

\section{The Survey Results}

Qualitative analysis of responses to open-ended questions "The DLS helped me ..."; "As a result of DLS learning..." allowed allocating 4 basic functions that define the DLS mission as career management technology: education; learning; facilitation of professional self-determination; socialization.

Education function- expanding horizons of listeners in IT sphere and acquaintance with the current state and key issues of the Data Science and Deep Learning with the most promising applications of neural networks. $21 \%$ of respondents named as the main result better orientation in the field of the Data Scientist and Deep Learning: the DLS "introduced me to the wonderful world of artificial intelligence ... has opened for me..."; "showed the novelties of the DL world, best practices, trends and common mistakes"; "gave an understanding of the essence of machine and deep learning"; "I touched the world of neural networks"; "formed a more integral view of the specialty."

The learning function is to translate mathematical tools needed to implement Deep Learning. 31\% of students named as the main result the obtaining of special competence: "studied mathematics necessary for the $D L$, understood, how the DL algorithms work, learned to teach the model"; "the course helped me improve my DL knowledge"; "professional skills have improved significantly"; "thanks to the course, I was able to build a good foundation for further DL learning"; "i learned not only to work with neural networks, but also to program better in general." A few critical remarks also most often concerned the training function of DLS: "I would like more explanations of the code, training cycles in general, a little more detailing on metrics, segmentation and detection"; "more practice in primary data analysis and Feature Engineering".

Facilitation function of professional selfdetermination: passing the DLS course allows the listener to assess both the degree of attractiveness of the Data Scientist specialty, and their own possibilities of mastering the competencies necessary for this area. This is especially important for schoolchildren - a realistic idea of the specialty reduces the risk of disappointment in the process of studying at university and in professional activity. $17 \%$ of respondents rated this course function as the main one; they acknowledged that DLS promoted self-determination in the professional field, building a trajectory for further education and work, creating the necessary motivation: "DLS helped me define the direction in the DL field"; "infected with interest in neural networks"; "DLS made it possible to believe in yourself and in your strengths"; "I seemed to come to life, again feeling like a student and now I'm ready to work on myself"; "Rethought my career"; "I understood my purpose"; "I made sure that I want to work in the field of Data Science"; "I learned that $D L$ is not fiction, but you need to study and read a lot"; "There was an understanding of DL, a vector of development and self-study on the topic"; "I fell in love with $D L$, now I know what I'm going to do. "KK"

Socialization function. Classes at DLS allow a school student to join the academic and professional community, students and graduates of universities - to expand contacts with colleagues and potential employers. Graduation from the DLS gives applicants a competitive advantage when applying for bachelor's and master's degrees at MIPT, for specialists - when applying for a more attractive and highly paid job. 19\% of respondents associate the main result of completing the course with various aspects of socialization - entering the professional community, establishing business and informal contacts, increasing competitiveness in the labor market: "I had a pleasant company to study the course"; "I felt a community of enthusiastic people, an exchange of interesting approaches and ideas"; "A vibrant community is a very strong point of this course"; "Listened to very interesting and fascinating lecturers"; "Made useful contacts"; "I can independently take part in many competitions"; "Made a small project that, I hope, will help with employment"; "There was something to add to the resume"; "Made a contribution to my project portfolio".

Quantitative analysis of closed-ended questionnaire questions. The questionnaire was conducted on the issues reflecting the distinguished functions of DLS as a career management tool (training itself, education, facilitation of professional selfdetermination, socialization).

\section{Survey Results of DLS - Listeners-Schoolchildren}

Recruiting gifted and motivated students to study at MIPT is the most important direct effect of DLS as a career guidance tool.

Table 1. Assessment by respondents of the success of the implementation of the learning function in DLS: "DLS helped me assess and improve my Deep Learning training"

\begin{tabular}{|c|c|c|c|c|c|}
\hline & $\begin{array}{l}\text { University } \\
\text { graduates }\end{array}$ & Bachelor students & Master's students & Schoolchildren & $\begin{array}{c}\text { Overall by the } \\
\text { sample }\end{array}$ \\
\hline Completely agree & $44.3 \%$ & $50 \%$ & $50 \%$ & $71.4 \%$ & $47.2 \%$ \\
\hline Rather agree & $38.6 \%$ & $31.6 \%$ & $40 \%$ & $28.6 \%$ & $36.8 \%$ \\
\hline Something in between & $11.4 \%$ & $18.4 \%$ & $10 \%$ & - & $11.8 \%$ \\
\hline Rather disagree & $2.4 \%$ & - & - & - & $2.8 \%$ \\
\hline Strongly disagree & $4.3 \%$ & - & - & - & $1.4 \%$ \\
\hline
\end{tabular}


Table 2. The respondents' assessment of the success of the implementation of the education function in DLS: "DLS allowed me to get acquainted with the current state of the IT sphere" (1), "DLS allowed me to find out the opinion of prominent IT industry specialists on the current state of machine learning"(2)

\begin{tabular}{|c|c|c|c|c|c|c|}
\hline & & $\begin{array}{l}\text { University } \\
\text { graduates }\end{array}$ & Bachelor students & Master's students & Schoolchildren & $\begin{array}{c}\text { Overall by the } \\
\text { sample }\end{array}$ \\
\hline \multirow[t]{5}{*}{1} & Completely agree & $31.9 \%$ & $39.4 \%$ & $40 \%$ & $14.3 \%$ & $35.4 \%$ \\
\hline & Rather agree & $33.3 \%$ & $30.8 \%$ & $30 \%$ & $71.4 \%$ & $36.8 \%$ \\
\hline & Something in between & $26 \%$ & $25.6 \%$ & $30 \%$ & $14.3 \%$ & $22.9 \%$ \\
\hline & Rather disagree & $7.2 \%$ & $3.6 \%$ & - & - & $4.2 \%$ \\
\hline & Strongly disagree & $1.4 \%$ & - & - & - & $0.7 \%$ \\
\hline \multirow[t]{5}{*}{2} & Completely agree & $21.7 \%$ & $21.7 \%$ & $30 \%$ & $28.6 \%$ & $27.8 \%$ \\
\hline & Rather agree & $40.6 \%$ & $40.6 \%$ & $40 \%$ & $42.9 \%$ & $33.3 \%$ \\
\hline & Something in between & $23.2 \%$ & $23.2 \%$ & $20 \%$ & $28.6 \%$ & $24.3 \%$ \\
\hline & Rather disagree & $11.6 \%$ & $11.6 \%$ & $10 \%$ & - & $12.5 \%$ \\
\hline & Strongly disagree & 2.95 & $2.95 \%$ & - & - & $2.1 \%$ \\
\hline
\end{tabular}

Table 3. The respondents' assessment of the success of the implementation of the function of facilitating professional selfdetermination in DLS: "DLS allowed me to understand better what this profession is" (1), "DLS allowed me to get a (more) interesting job for me in the future"(2)

\begin{tabular}{|c|c|c|c|c|c|c|}
\hline & & $\begin{array}{l}\text { University } \\
\text { graduates }\end{array}$ & Bachelor students & Master's students & Schoolchildren & $\begin{array}{c}\text { Overall by the } \\
\text { sample }\end{array}$ \\
\hline \multirow[t]{5}{*}{1} & Completely agree & $37.1 \%$ & $47.4 \%$ & $30 \%$ & $28.6 \%$ & $40.3 \%$ \\
\hline & Rather agree & $37.1 \%$ & $39.5 \%$ & $60 \%$ & $71.4 \%$ & $41.7 \%$ \\
\hline & Something in between & $17.1 \%$ & $7.9 \%$ & $10 \%$ & - & $11.8 \%$ \\
\hline & Rather disagree & $8.6 \%$ & $5.3 \%$ & - & - & $6.3 \%$ \\
\hline & Strongly disagree & - & - & - & - & - \\
\hline \multirow[t]{5}{*}{2} & Completely agree & $24.6 \%$ & $32.4 \%$ & $30 \%$ & $14.3 \%$ & $27.1 \%$ \\
\hline & Rather agree & $39 \%$ & $41.1 \%$ & $60 \%$ & $71.4 \%$ & $43.1 \%$ \\
\hline & Something in between & 21.7 & $24.3 \%$ & $10 \%$ & $14.3 \%$ & $20.1 \%$ \\
\hline & Rather disagree & $11.6 \%$ & $2.7 \%$ & - & - & $7.6 \%$ \\
\hline & Strongly disagree & $2.9 \%$ & - & - & - & $2.1 \%$ \\
\hline
\end{tabular}

Table 4. Respondents' assessment of the success of the socialization function in DLS: Studying in DLS will help me get a (better) paying job"

\begin{tabular}{lccccc}
\hline & $\begin{array}{c}\text { University } \\
\text { graduates }\end{array}$ & Bachelor students & Master's students & Schoolchildren & $\begin{array}{c}\text { Overall by the } \\
\text { sample }\end{array}$ \\
\hline Completely agree & $14.3 \%$ & $27.0 \%$ & $20 \%$ & - & $18.8 \%$ \\
Rather agree & $35.7 \%$ & $45.9 \%$ & $60 \%$ & $71.4 \%$ & $43.1 \%$ \\
Something in between & $32.9 \%$ & $21.6 \%$ & $20 \%$ & $14.3 \%$ & $26.4 \%$ \\
Rather disagree & $12.9 \%$ & $5.4 \%$ & - & $14.3 \%$ & $9.0 \%$ \\
Strongly disagree & $14.3 \%$ & $27.0 \%$ & - & - & $2.8 \%$ \\
\hline
\end{tabular}

According to the survey data, $85.7 \%$ of the respondents-schoolchildren plan to enroll in the MIPT; $14.3 \%$. of schoolchildren plan to enroll in the specialty of the IT profile, but have not yet decided what university to enter. For applicants entering the MIPT, graduating from the DLS gives a competitive advantage (points for individual achievement). $71 \%$ of schoolchildren admitted that this fact is significant for them; for $29 \%$, this was not significant and was not among the motives for studying in the DLS.

Assessment by schoolchildren of opportunities to join the professional community with the help of DLS: $71.4 \%$ of schoolchildren agree with the statement "DLS allowed me to get to know MIPT students and alumni", 28,6\% disagree. "DLS allowed me to get to know (establish contacts, make friends) with the guys with whom I might study together at the university": rather disagree - 57\%; something in between $-43 \%$. There are no respondents who agree with the statement.

\section{Assessment by Respondents of Offline and Online Forms of Education in DLS}

See Tables 5-7.

\section{Motivation by Respondents to Prefer Offline, Online or Blended Learning}

Respondents who would prefer an offline lesson: "live communication is always better"; "No distractions, more

involvement, more opportunity to ask questions"; "Offline, I would not be only a spectator, but a participant"; "You can immediately run some moments on your laptop and participate more interactively in the event"; "Watching a seminar and doing it yourself are very different things"; "Live" seminars and lectures motivate you to do much more"; 
Table 5. The use of classroom and distance forms of classes by various groups of DLS listener

\begin{tabular}{|c|c|c|c|c|c|}
\hline & $\begin{array}{l}\text { University } \\
\text { graduates }\end{array}$ & $\begin{array}{l}\text { Bachelor } \\
\text { students }\end{array}$ & $\begin{array}{l}\text { Master's } \\
\text { students }\end{array}$ & Schoolchildren & $\begin{array}{c}\text { Overall by the } \\
\text { sample }\end{array}$ \\
\hline $\begin{array}{l}\text { Attended all classroom lectures, seminars; video } \\
\text { lectures and video seminars of these lectures have } \\
\text { not been additionally watched }\end{array}$ & $3.4 \%$ & $15.8 \%$ & $10 \%$ & - & $7.6 \%$ \\
\hline Attended most of the classroom lectures, seminars & $14.3 \%$ & $13.2 \%$ & $10 \%$ & $14 \%$ & $11.8 \%$ \\
\hline Attended about half of classroom lectures, seminars & $5.1 \%$ & $13.2 \%$ & $10 \%$ & & $6.2 \%$ \\
\hline $\begin{array}{l}\text { Attended a small number of classroom lectures, } \\
\text { seminars }\end{array}$ & $10.2 \%$ & $7.9 \%$ & $10 \%$ & $14 \%$ & $9 \%$ \\
\hline Did not attend classroom lectures, seminars & $67.8 \%$ & $50 \%$ & $60 \%$ & $72 \%$ & $65.3 \%$ \\
\hline
\end{tabular}

Table 6. The active use of the video course by various groups of DLS listeners

\begin{tabular}{|c|c|c|c|c|c|}
\hline & $\begin{array}{l}\text { University } \\
\text { graduates }\end{array}$ & $\begin{array}{l}\text { Bachelor } \\
\text { students }\end{array}$ & $\begin{array}{l}\text { Master's } \\
\text { students }\end{array}$ & Schoolchildren & $\begin{array}{l}\text { Overall by the } \\
\text { sample }\end{array}$ \\
\hline $\begin{array}{l}\text { Looked through all the lectures, including those } \\
\text { attended personally }\end{array}$ & $48.6 \%$ & $42.1 \%$ & $10 \%$ & $71.4 \%$ & $44.4 \%$ \\
\hline $\begin{array}{l}\text { Looked through only those that I did not attend } \\
\text { personally }\end{array}$ & $47.1 \%$ & $42.1 \%$ & $70 \%$ & $14.3 \%$ & $43.1 \%$ \\
\hline Looked through some lectures attended personally & 1. $4 \%$ & $10.5 \%$ & $20 \%$ & $14.3 \%$ & $8.3 \%$ \\
\hline Did not look through the lectures at all & $2.8 \%$ & $5.3 \%$ & - & - & $4.2 \%$ \\
\hline
\end{tabular}

Table 7. Comparative assessment of the preference for offline learning and video resources: "If it would be equally convenient for you to attend a "live" lecture (seminar) in the classroom or watch a video lecture (video seminar) in good quality, what would you choose?"

\begin{tabular}{|c|c|c|c|c|c|}
\hline & $\begin{array}{l}\text { University } \\
\text { graduates }\end{array}$ & $\begin{array}{l}\text { Bachelor } \\
\text { students }\end{array}$ & $\begin{array}{l}\text { Master's } \\
\text { students }\end{array}$ & Schoolchildren & $\begin{array}{c}\text { Overall by the } \\
\text { sample }\end{array}$ \\
\hline Would attend "live" lecture in the classroom & $31.9 \%$ & $42.1 \%$ & $40 \%$ & $42.9 \%$ & $38.1 \%$ \\
\hline Would watch a video lecture & $17.4 \%$ & $26.3 \%$ & $20 \%$ & - & $22.8 \%$ \\
\hline Would attend "live" lecture and watch a video record & $44.9 \%$ & $26.3 \%$ & $40 \%$ & $57.1 \%$ & $37.6 \%$ \\
\hline Different & $6.7 \%$ & $5.3 \%$ & - & - & $1.5 \%$ \\
\hline
\end{tabular}

"Interactivity"; "The opportunity to communicate live with students and the teacher increases the quantity and quality of acquired skills; additional opportunities for "networking"; development of soft-skills; exchange of skills and experience; teamwork"; "The live lecture leaves more impressions."

Respondents who would prefer an online format (video lecture, video seminar): "a lot of time is saved, and you can get a lot of advantages from the video - from rewatching difficult parts, up to $1.5 x$ the speed of easy or already familiar parts"; "When you work, it's easier to find time for a video lecture"; "I live in another city"; "Logistically optimal"; "You can conveniently take notes, stop the video and look for a question"; "I am a slow thinker"; "Lectures are drawn out due to questions, etc.; "It is more convenient to watch the recording at speed"; "Information is presented in a more structured manner and the lecture itself takes less time; questions can be raised in the chat; easier to re-watch "; "You cannot" pause the lecturer "and view information of interest on the Internet."

Respondents who would prefer a mixed format: "I may not remember or understand from the first time, lectures and videos complement each other perfectly in the process of learning"; "Live lectures allow you to ask questions and chat with students, you can watch video + recall something"; "You can't keep up with everything live, so if anything, you can watch the video after the seminar, but live is still better"; "Live lecture is better remembered, and the video can be rewound";
"Video recording is useful for working through incomprehensible moments in a "live "lecture."

\section{DISCUSSION}

The peculiarity of DLS technology is that with the widespread use of digital content and distant forms of work, an orientation is towards a mixed format. Learning that takes place entirely online is a forced and temporary measure. MOOCs on the Coursera platform predominantly involve automatic assessment of homework and tests, the use of formal and statistical assessment methods wherever possible (Korableva et al., 2019). DLS is implemented with the active support of teachers and tutors; the opportunity for the listener to receive offline and online personalized feedback and advice increases as the course progresses. The survey shows that listeners highly appreciate the possibility of "live communication" during offline lectures and seminars for socialization and facilitation of professional self-determination, maintaining interest in the course and motivation to mastering it completely. The community is also formed more successfully if the offline format is available to at least some of the listeners. This is consistent with evidence that university students were significantly less satisfied with the course they took 
online than they did in the classroom (Summers et al., 2005).

\section{CONCLUSION}

The mission of the DLS as a tool for career management and recruiting talented youth in the field of Deep Learning and, more broadly, Data Science involves the implementation of the functions of training itself, education, facilitation of professional self-determination, and socialization.

DLS students most often associate satisfaction with the course with the learning function itself, less often with the educational and socialization function, and even less often with the facilitation function.

Both online and mixed DLS options are effective as a career management tool for students and professionals.

Concerning schoolchildren, the existing technology is successful in selecting the elite of the student body - the most competent and motivated to acquire the Data Scientist profession. The use of DLS for mass career guidance of potential applicants is possible with the expansion of the offline component, which is more attractive for schoolchildren. The creation of regional branches, which is included in the immediate plans of the DLS leadership, will facilitate students' conscious self-determination in the profession and entry into the academic and professional community. The introduction of a propaedeutic module, tutoring and mentoring strengthening will increase the availability of DLS without unacceptable simplifying the course content as a whole.

The majority of the respondents considers the blended learning format - duplication of offline classes using digital content the most attractive. Schoolchildren give such an assessment more often than others; university graduates and master students give such assessment a little less often, compared to bachelor's students. Bachelor's students, schoolchildren and master's students more often agree to restrict themselves to offline classes; university graduates agree to such a format more rarely. For all groups of listeners, the online learning format as the only one is the least attractive; no student considers such an organization of education in DLS desirable.

Listeners note the different functionality of offline classes (greater involvement; greater motivating effect; interactivity; emotional contact with teachers and colleagues; inclusion in the professional community) and of online forms (the possibility of distant work, accessibility regardless of place of residence; the ability to independently regulate the mode and pace of work; the possibility of repeated views; the ability to fully study the material with the use of additional information sources if necessary).
At the same time, the majority of schoolchildren, master's students and university graduates, as well as half of bachelor's students, did not actually attend lectures and seminars in the classroom; only 19\% of all DLS listeners attended all (bigger part) face-to-face classes. The majority of schoolchildren, half of bachelor's students and university graduates, and a third of master's students intensively used the video course as the only form of work or in combination with face-toface classes. The number of listeners who did not use the video resource at all is insignificant.

\section{LIMITATIONS OF THE STUDY}

Within the framework of this study, differentiation and comparison of the assessments of DLS students with different degrees of success in mastering the course were not carried out. The voluntary participation in the survey limited the number of respondents who left the course early. The insignificance of the number of schoolchildren who completely completed the course is associated with both the objective difficulty of the content and the imperfection of the technology. The assessment of the actual use of online or blended forms was carried out without taking into account the geography of residence of the participants and the possibility of attending offline classes.

Author contributions: All authors have sufficiently contributed to the study, and agreed with the results and conclusions.

Funding: This paper has been supported by the Kazan Federal University Strategic Academic Leadership Program.

Declaration of interest: No conflict of interest is declared by authors.

\section{REFERENCES}

Broadbent, J., \& Poon, W. L. (2015). Self-regulated learning strategies \& academic achievement in online higher education learning environments: A systematic review. Internet and Higher Education, 27(573) 1-13. https://doi.org/10.1016/j.iheduc. 2015.04.007

Buhr, E. E., Daniels, L. M., \& Goegan, L. D. (2019). Cognitive appraisals mediate relationships between two basic psychological needs and emotions in a massive open online course. Computers in Human Behavior, 96, 85-94. https:// doi.org/10.1016/j.chb.2019.02.009

Chen, K.-C., \& Jang, S.-J. (2010). Motivation in online learning: Testing a model of self-determination theory. Computersin Human Behavior, 26(4), 741-752. https://doi.org/10.1016/j.chb.2010.01.011

Gimaliev, V. G., Prokopyev, A. I., Vershinin, V. P., Ivanova, M. E., Erkibaeva, G. G., Aytuganova, J. I., \& Alexandrova, N. S. (2020). Public relations in organizations in student view: Accumulator of management tools or formation of partnership and friendly relations. Journal of Environmental 
Treatment Techniques, 8(4), 1326-1330. https:/ / doi.org/10.47277/JETT/8(4)1230

Goodfellow, I., Bengio, Y., Courville, A., \& Bengio, Y. (2016). Deep learning. MIT press.

Gorshkov, M. K., \& Klyucharev, G. A. (2011). Lifelong learning the context of modernization. M: Russian Academy of Sciences Institute of Sociology RAS, Ministry of Education and Science of the Russian Federation "Center for Sociological Research" (pp. 232-235). https://www.hse.ru/data/2014/0-9/30 /1100432931/Ключарев,\%20Диденко,\%20Латов, \%20Латова.\%20Непрерывное....pdf

Hsu, H.-C. K., Wang, C. V., \& Levesque-Bristol, C. (2019). Reexamining the impact of self-determination theory on learning outcomes in the online learning environment. Education and Information Technologies, 24(3) 2159-2174. https://doi.org/ 10.1007/s10639-019-09863-w

Kalugina, O. A., Vasbieva, D. G., Shaidullina, A. R., Sokolova, N. L., \& Grudtsina, L. Y. (2018). ESP blended learning based on the use of smart coursebook. XLinguae, 11(2), 445-454. https:// doi.org/10.18355/XL.2018.11.02.36

Korableva, O., Durand, T., Kalimullina, O., \& Stepanova. (2019). Usability testing of MOOC: Identifying user interface problems. Proceedings of the 21st International Conference on Enterprise Information Systems (pp. 468-475). https://doi.org/10.5220/ 0007800004680475

Kvon, G. M., Vaks, V. B., Kalimullin, A. M., Bayanova, A. R., Shaidullina, A. R., Dolzhikova, A. V., \& Lapidus, N. I. (2019). Developing the informational and digital environment of a university: Problem analysis and assessment. Eurasia Journal of Mathematics, Science and Technology Education, 15(10), em1767. https:// doi.org/10.29333/ ejmste/ 109503

LeCun, Y., Bengio, Y., \& Hinton, G. (2015). Deep learning. Nature, 521(7553), 436-444. https:// doi.org/10.1038/nature14539

Professionalising career guidance. (2009). Practitioner competences and qualification routes in Europe. Cedefop-Luxembourg: Office for Official Publications of the European Communities, 4, 107-110. https:/ / www .researchgate.net/publication/317504302_The_Eur opean_Status_for_Career_Service_Provider_Crede ntialing_Professionalism_in_European_Union_EU _Guidance_Policies

Radchenko, L. R. (2011). The policy of the British colonial authorities in India in the field of higher education. Proceedings of the Samara Scientific Center of the Russian Academy of Sciences, 13(3), 187-189. https://cyberleninka.ru/article/n/politikabritanskih-kolonialnyh-vlastey-v-indii-v-sferevysshego-obrazovaniya
Razumovskaya, M. I., Larionova, A". A., Zaitseva, N. A., Petrina, O. A, Vinogradova, M. V., Nagay, N. G., \& Takhumova, O. V. (2019). Models of integrated interactions organization in the field of environmental education. Journal of Environmental Treatment Techniques, 7(Issue 4), 576-580.

Razumovskaya, M., Zaitseva N. A., Larionova, A. A., Chudnovskiy, A. D., \& Breusova, E. A. (2018). Prospects for applying various forms of organizational integration to improve the quality of education. Astra Salvensis, 6, 348-362.

Salikhova, N. R., Lynch, M. F., \& Salikhova, A. B. (2020). Psychological aspects of digital learning: A selfdetermination theory perspective. Contemporary Educational Technology, 12(2), ep280. https://doi.org/10.30935/cedtech/8584

Shafranov-Kutsev, G. F., \& Tolstoguzov, S. N. (2014). Vocational guidance practices of the university. Logos. https:// doi.org/10.17853/1994-5639-20188-46-65

Shinkevich, M. V., Mashkin, N. A., Ishmuradova, I. I., Kolosova, V. V., \& Popova, O. V. (2020). Management of sustainable consumption of energy resources in the conditions of digital transformation of the industrial complex. International Journal of Energy Economics and Policy, 10(5), 454-460. https://doi.org/10.32479/ijeep. 10202

Sukhareva, L. M. (2019). Career guidance activity as an object of pedagogical research: A retrospective analysis. Issues of Territorial Development, 1(46), 1-10. https://doi.org/10.15838/tdi.2019.1.46.5

Summers, J. J., Waigandt, A., \& Whittaker, T. A. (2005). A comparison of student achievement and satisfaction in an online versus a traditional face-toface statistics class. Innovative Higher Education, 29(3), 233-250. https://doi.org/10.1007/s10755005-1938-x

Sun, Y., Ni, L., Zhao, Y., Shen, X.-L., \& Wang, N. (2019). Understanding students' engagement in MOOCs: An integration of self-determination theory and theory of relationship quality. British Journal of Educational Technology, 50(6), 3156-3174. https://doi.org/10.1111/bjet.12724

Tolstoguzov, S. N. (2015). Experience of career guidance work abroad. Education and Science, 1(120), 151-165. https://www.edscience.ru/jour/article/view/35 $5 / 351$

Tsarapkina, Yu. M. (2017). The use of information technology as a basis for professional selfdetermination. Bulletin of Peoples' Friendship University of Russia Series: Informatization of education, 4(14), 430-434. https://doi.org/10.22363 /2312-8631-2017-14-4-430-434 
Tugun, V., Bayanova, A. R., Erdyneeva, K. G., Mashkin N. A., Sakhipova, Z. M., \& Zasova, L. V. (2020). The opinions of technology supported education of university students. International Journal of Emerging Technologies in Learning, 15(23), 4-14. https://doi.org/10.3991/ijet.v15i23.18779

Wang, C. V., Hsu, H.-C. K., Bonem, E. M., Moss, J. D., Yu, S., \& Nelson, D. B., \& Levesque-Bristol, C. (2019). Need satisfaction and need dissatisfaction: A comparative study of online and face-to-face learning contexts. Computers in Human Behavior, 95, 114-125. https:/ / doi.org/10.1016/j.chb.2019.01.034
Wiese, M., Van Heerden, C. H., \& Jordaan Y. (2010). The role of demographics in students' selection of higher education institutions. Act a Commercii, 10(1), 150-163. https://doi.org/10.4102/ac.v10i1. 124

Yermilova, V. V., Loktionova, Y. N., Smirnov, A. V., Seregina, T. N., \& Prokopyev, A. I. (2019). The development of a personal wellbeing index indicator of the life satisfaction. Espacios, 40(25), Article number 16.

\section{http://www.ejmste.com}

